\title{
USER SATISFACTION FROM THE PERSPECTIVE OF ACCEPTABILITY IN THE FAMILY HEALTH SCENARIO ${ }^{1}$ SATISFAÇÃO DO USUÁRIO NA PERSPECTIVA DA ACEITABILIDADE NO CENÁRIO DA SAÚDE DA FAMÍLIA \\ SATISFACCIÓN DEL USUARIO EN LA PERSPECTIVA DE LA ACEPTABILIDAD EN EL ESCENARIO DE LA SALUD DE LA FAMILIA
}

\author{
Vanessa Pirani Gaioso², Silvana Martins Mishima
}

\begin{abstract}
${ }^{1}$ This study was funded by Conselho Nacional de Desenvolvimento Científico e Tecnológico (CNPq), process no ${ }^{351742 / 1998-0}$
${ }^{2}$ RN, M. Sc. in Public Health Nursing School of Nursing at Ribeirão Preto, University of São Paulo. Doctoral Student in the School of Nursing, University of Alabama at Birmingham (UAB). Alabama, United States of America.

${ }^{3}$ RN, Associate Professor Infant-Maternal and Public Health Nursing Department School of Nursing at Ribeirão Preto University of São Paulo. São Paulo, Brasil.
\end{abstract}

KEYWORDS: Health services evaluation. Primary health care. Consumer satisfaction. Family health.

PALAVRAS-CHAVE: Avaliação de serviços de saúde. Atenção primária à saúde. Satisfação dos consumidores. Saúde da família.

PALABRAS CLAVE: Evaluación de servicios de salud. Atención primaria de salud. Satisfacción de los consumidores. Salud de la familia.
ABSTRACT: The purpose of this study was to assess users' acceptability of the care offered and delivered by Family Health teams in Ribeirão Preto, São Paulo, Brazil. This exploratory-descriptive study was based on a quantitative-qualitative approach method. The sample consisted of 171 users, registered at the four Family Health Units that cover the basic area of a secondary service. The study used semi structured interviews with analytical dimensions: infrastructure, accessibility, and team-user relationships. Descriptive statistics was used for calculations of standard deviation, mean and median, assisted by Statistical Package for Social Science, and thematic analysis. The results show predomination of the female gender $(87,7 \%)$, age older than 60 years old (31.0\%), and monthly income inferior to two minimum monthly salaries (34\%). Users indicated considerate and affective interpersonal relations as one point of satisfaction and one of the aspects that differentiates health care. Dissatisfaction predominated in terms of environment, a long time spent in the waiting room, and organizational accessibility,impairing care longitudinality and continuity. Studies within this theme give opportunities to users, strengthening their participation in the planning processes and exercising social control.

RESUMO: Objetiva-se avaliar a aceitabilidade dos usuários quanto à oferta e prestação de assistência na Saúde da Família em Ribeirão Preto - SP, Brasil. Estudo quanti-qualitativo de caráter exploratório-descritivo, sendo entrevistados 171 usuários cadastrados nas quatro Unidades de Saúde da Família que cobrem a área básica de um serviço de referência secundária. Utilizou-se entrevista semi-estruturada com dimensões analíticas: infraestrutura, acessibilidade, relação equipe-usuário, resolutividade. Utilizou-se estatística descritiva com cálculos de desvio padrão, média e mediana, auxiliado pelo Statistical Package for Social Science, e análise temática. Predominou: sexo feminino $(87,7 \%)$, idade acima de 60 anos $(31,0 \%)$ e renda mensal inferior a dois salários mínimos (34\%). É apontada satisfação nas relações marcadas por afetividade e atenção, aspectos diferenciais na atenção à saúde. A insatisfação se volta: ambiência, tempo de espera alto para consultas, acessibilidade organizacional, prejudicando longitudinalidade e continuidade da assistência. Estudos desta natureza permitem expressão dos usuários, contribuindo para planejamento e controle social.

RESUMEN: El objetivo de esta investigación es evaluar la aceptabilidad de los usuarios con relación a la oferta y prestación de atención por los equipos de Salud de la Familia de Ribeirão Preto, SP - Brasil. Se trata de una investigación de carácter exploratorio-descriptivo, centrándose en una aproximación cuantitativa y cualitativa. La población del estudio abarcó a 171 usuarios catastrados en las cuatro Unidades de Salud de la Familia que atienden el área básica de un servicio secundario. Los datos empíricos fueron recolectados mediante entrevista parcialmente estructurada, con la utilización de dimensiones analíticas: infraestructura, accesibilidad, relación equipo-usuario y resolutividad. Para el análisis de los datos cuantitativos, se utilizó estadística descriptiva con cálculos de desvío patrón, media y mediana, recurriendo para ello, al auxilio del software Statiscal Package for Social Science. Para el análisis de los datos cualitativos, se empleó el análisis temático. El resultado del análisis de los datos mostró un predominio de: sexo femenino (87,7\%), con más de 60 años de edad (31,0\%), y con una renta mensual inferior a dos salarios mínimos (34\%). Los usuarios indicaron como uno de los puntos de satisfacción, relaciones interpersonales atentas y afectivas, uno de los aspectos diferenciales en la atención a la salud. Las insatisfacciones predominaron en relación al ambiente, mucho tiempo de espera y accesibilidad organizacional, perjudicando la longitudinalidad y la continuidad de la atención. Estudios de esta naturaleza permiten la expresión de los usuarios, contribuyendo en los procesos de planificación y ejerciendo el control social.

Vanessa Pirani Gaioso

Address: Escola de Enfermagem de Ribeirão Preto (EERP),

Universidade de São Paulo (USP)

Av. Bandeirantes, 3900

14.040-902 - Campus Universitário, Ribeirão Preto, SP, Brazil.

Email: vgaioso@uab.edu

Texto Contexto Enferm, Florianópolis, 2007 Out-Dez; 16(4): 617-25.
Artigo original: Pesquisa

Recebido em: 27 de fevereiro de 2007 Aprovação final: 15 de outubro de 2007 


\section{INTRODUCTION}

The evaluation of services in the field of Public Health is extremely important because it allows the offering of directions and options in the process of planning and it can also favor the technical and social control of the services and programs delivered to society. Studies on the evaluation of health services, programs, and of specific actions have been produced. However, there is a lack of scientific production concerning users' satisfaction regarding services delivered in primary health care, especially those within Family Health. It is important to point that the Family Health Strategy (SFH) was implemented in Brazil more than a decade ago and has been evaluated by the Ministry of Health (HM) itself. The Ministry has pointed out the need for local studies in order to analyze how the services related to the users. ${ }^{1-2}$

There are several definitions in the theoretical approaches regarding the quality of care in the evaluation of health practices, while the term acceptability is that which is directly related to the expectations and satisfaction of the users. ${ }^{3}$ Acceptability is defined as a set of factors in the physicianpatient relationship and patient-health care system. Acceptability comprehends the accessibility, the physician-patient relationship (here we include the health team-user relationship), the environment and building, patient's preferences regarding the effects and treatment costs and everything the patient considers being fair and just. ${ }^{3}$

When considering acceptability, the utilization of health services will always refer to needs and expectations, individual or collective, related to a health problem, or to a set of problems. When using such services, the individual may or may not have his/her needs and expectations met; and the level of satisfaction allows one to infer quality in several moments of assistance, in an interactive process that occurs from the entrance to the exit of the health unit. ${ }^{4}$

When evaluating health systems and/or health services, we have to bear in mind that the services/actions delivered have the users as a goal, who are part of the organizational process and of the delivery process of these actions. ${ }^{5}$ In this sense, the analysis of those involved in the services/programs regarding their experiences must be recognized as rational and analyzed in the historical and social context of its production.

In this study, we are interested in analyzing the users' satisfaction from the perspective of acceptability, with the possibility of contributing to the evaluation and quality of health services, stimulating processes of reflection and intervention of these services for the organization, and planning health actions. Therefore, this study aims to evaluate the users' acceptability regarding the assistance offered and delivered by the Family Health teams in the municipality of Ribeirão Preto, São Paulo, Brazil.

\section{METHOD}

This is an exploratory-descriptive research with a quantitative-qualitative approach. The use of a qualitative-quantitative approach is desirable in evaluation processes because of the heterogeneity and complexity of the health services. The use of these two approaches allows for a deeper understanding of the internal dynamic of the phenomenon studied and consequently, the understanding of the multiple aspects of the services studied. ${ }^{5}$

The research was carried out in Ribeirão Preto, in the Northeast São Paulo, Brazil. According to the database of the Department of Informatics of the Brazilian National Health Care System (Sistema Único de Sanide - SUS), the population of the city in 2006 was 559,650 inhabitants, making Ribeirão Preto one of the largest in the state of São Paulo and Brazil. The city is ascientific, technological, and human resources capacitating center in several areas of knowledge, especially in the health area. In the process of regionalization of care, the municipality assumed the condition of a assistance center, becoming a reference in medium and high levels of complexity.

This study was performed in the western district of the municipality", in four Family Health Units (FHU) that deliver care to the basic area of the Basic and District Health Unit (UBDS) of the West District, which counts upon services linked to the University of São Paulo.

Unlike other Basic and District Health Units of the municipality, the population of the basic

\footnotetext{
The municipality comprises 5 health districts, organized in a way to provide the regionalization of the attention and the hierarchy of the health services. Each Health District is organized by a territorial area of around 100 thousand inhabitants. It comprises of one Basic and District Health Unit (UBDS) that offers specialized care and 24-hour assistance for emergencies for the population of its district area, and basic care for the population in its proximity. Each District has a certain number of Basic Health Units (UBS), which offer basic care to the registered members of the population, and Family Health Units (USF).
} 
area of this service is covered by Family Health teams that are organized in four Units (FHU White, FHU Red, FHU Blue e FHU Green). This is the main reason these units were selected for this study. In addition, these were the first Family Health Units implemented and qualified in the municipality in $2001^{\dagger}$.

For the development of this research, the norms of Resolution CNS 196/96 of the National Research Ethical Committee were followed. The research was also approved by the Ethical Research Committee of the Center Health School of the Medical School of the University of São Paulo, protocol number $\mathrm{N}^{\circ}$ 0185/CEP/CSE-FMRPUSP. Subjects who accepted to participate in this study signed the Informed Consent document.

For the selection of subjects for this study, we considered $5 \%$ of all the families registered in each of the Family Health units selected. Thus, for each unit, from the data of the Information System of the Basic Care - SIAB and from the report "List of Families by Micro-area" of each unit provided by the referred system, a random sample was selected, considering $5 \%$ of the families of each unit.

Considering one respondent per household, the following inclusion criteria were used:individualsolder than 18 years old, if possible the responsible member of the household, who were at home at the moment of the interview; having at least one experience with administrative or health assistance in the Family Health Unitintheprevioussix months. Thislast criterionaimed to reach not only registered users but service users.

The semi-structured interview was used for the data collection, which was recorded and performed in only one moment. The instrument used to support the interview had general questions related to the characterization of the respondent, and the second part of the interview had questions related to the user's satisfaction on the perspective of acceptability. To put the concept acceptability in practice, analytical dimensions were used: infra-structure, accessibility, team-user relationship, problem-solving capacity. The selection of these analytical dimensions were based on the theoretical referential adopted and following the National Research of Evaluation of the SUS Users' Satisfaction, performed by the Ministry of Health in 2006. ${ }^{2}$

It is important to justify the use of these analytical dimensions in the construction of the instrument of this study due to the lack of standardization of instruments in the same country, which makes the comparison of results between studies difficult. ${ }^{7}$

The data collection was carried out in the period of July to October of 2006, and 171 interviews were performedin thefourFamilyHealthUnits. Forthedata quantitative analysis, a specific database was organized in Excel, with special care for: digitization, validation, and correction of errors. Then, the data was cross tabulated using theStatistical PackageforSocial Science (SPSS) version 14.0 for Windows. Descriptive statistics analysis was used to calculate the standard deviation, the average, and the median of the data.

The qualitative data obtained in the users' speech in the interviews was analyzed according to the content analysis. For this stage of the analysis, the material originated from theFamily Health unitsFHUBlue and FHU Green were selected due to their homogeneity and similarity in their areas of scope.

\section{THE SUBJECTS AND THEIR EXPRES- SION OF SATISFACTION/DISSATISFAC- TION}

Among the 171 users, the female gender predominated (87.7\%). In terms of age, those older than 60 years old were the majority with $53(31.0 \%)$ people, followed by those 51 to 59 years old with $36(21.1 \%)$ people. Regarding their marital status, $53.8 \%$ of the interviewed were married, $15.8 \%$ widowed, $15.2 \%$ single, $10.5 \%$ divorced, and $4.7 \%$ had fixed partners.

The average time of residence in the area was 15.41 years, $81.3 \%$ were not employed and the majority were housewives, followed by retired people. Regarding the subjects' educational level, 50.3\% had incomplete elementary school, followed by $18.7 \%$ with complete secondary school and $34 \%$ of the subjects had a monthly income inferior to two minimum salaries. From the total interviewed, only $25.7 \% \mathrm{had}$ health insurance, with coverage for two people in the family on average. The main reasons for seeking a health service was medical consultation $(66.7 \%)$ and the presence of morbidity (46.8\%).

The interviewees use the Family Health unit monthly (39.2\%) andyearly (40.9\%) by scheduled medical consultations $(90.1 \%)$, use of procedures in general $(36.8 \%)$, while in the majority for controlling arterial

\footnotetext{
$\dagger$ These Family Health Units are connected to the University of Sao Paulo, through agreement with the Municipal Health Secretary of Ribeirão Preto, State Secretary of Health of São Paulo and the Ministry of Health.
} 
blood pressure and for eventual consultations (11.7\%). Only three people reported using nursing consultations and participating in educational activities. Two people reported household visits.

\section{Access and accessibility of the Family Health Units}

Access refers to the possibility of using health services when necessary; expressed characteristics of supply that favor or hinder people's capacity to use the health services when needed. Access barriers originate in the system and the health service characteristics. The availability of services and their geographical distribution, the availability and the quality of human and technological resources, the funding mechanisms, the assistance model, and information about the system are characteristics of supply that affect access. ${ }^{8}$

Primary health care comprises aspects related to the first contact, continuing care, integrality, and coordination. The attention in the first contact refers to characteristics of accessibility of the units, such as, available working hours, facility of the collective transportation, buildingsadapted tophysically-deficient people, possibility to scheduleappointments, timespent in the waiting room for such appointments, and no linguistic or cultural barriers. ${ }^{9}$

Such accessibility allows people to reach the services, that is, this is one of the aspects of the structure of a system or health unit required for the first contact. It is the structural element necessary for the first care. To offer it, the local of assistance must be easily accessible and available. ${ }^{9}$

Accessibility is the result of a set of factors of different dimensions that can be classified as geographical, organizational, socio-cultural, and economic order. ${ }^{10}$

A significant expression of satisfaction (93.6\%) was observed among the users, when questioned about the geographical accessibility. When the empirical material originated from the interviews of the FHU Blue and Green was analyzed, we verified the recurrent expression of satisfaction, which is in agreement with the quantitative data. Users reported the good localization of the FHU, the short distance between the unit and their houses, the possibility of going on foot to the unit and the short time to travel, reinforcing the facility to get to the units and the benefits to the neighborhood.

The geographical accessibility must be measured considering how long it takes the subject to reach the health assistance through the public transportation. In addition to the distance between the population and the resources, the physical characteristics of the territory must also be considered, since they can impede or hinder the population's access. ${ }^{10}$

The organizational accessibility is related to the obstacles that come from the organization of the assistance resources, both at the entrance and inside the health unit. ${ }^{10}$ This is a central issue in the narratives of the FHU Blue and Green users, who express their dissatisfactions regarding obstacles that hinder the initial contact (working hours of the FHU, access to consultation) as in the inside of the health unit (nondistribution of medication and procedures; references; time spent in the waiting room) since these units are the entrance to the health system.

There was a high level of approval regarding the FHU working hours, $60.3 \%$ of the users classified it as excellent and good, while around $40 \%$ classified it as regular, poor, and extremely poor. This contradiction can be better understood if we analyze the content of the interviews of the FHU Blue and Green users. A highexpectancyinextending workinghours, even when classifying it as good and excellent can be observed in their speeches. Additionally, some of them expressed their perception that more professionals were needed in order to cover for others in the shift turns.

Others manifested dissatisfaction and a lack of understanding regarding the hours and periods the FHU stays closedfor its team meetings. These meetings aim to discuss situations experienced by the families assisted and who need an approach not only in medical terms but also in terms of health and social aspects. There are also moments for the team's permanent education and the discussion of administrative actions. Some suggested these meetings should be held after the working hours or before the unit is opened.

However, there are some users who are satisfied with the working hours and say there is no need to extending working hours since there are backup services available 24 hours near the FHU.

Studies ${ }^{11}$ on satisfaction present high levels of users' satisfaction. These results are criticized on the allegation that users have difficulties in pointing out negative aspects in the health service, afraid their opinions would compromise their access to the services.

The availability, type, quantity of services, and resources (financing, human, and technological), geographical localization, local medical culture, ideology of the health deliverer, among others, are aspects of supply that influence the consumption pattern of the individuals. On the other hand, the individual choices 
are also crucial, while not all the needs are converted in demands and not all the demands are met. ${ }^{12}$

The majority of the users of the four services studied is satisfied both with the access to the scheduled appointment (62\%) and with the access to the eventual appointment (66.6\%). However, when analyzing the narratives we perceive that the majority of the users had expectations and wished the scheduled appointment to be scheduled in a shorter period of time. They report it takes three months on average to schedule an appointment. Also, regarding the eventual appointment, despite complaints for the time spent in the waiting room, users express satisfaction for getting assistance on the same day. It can be observed that users have difficult expressing their dissatisfactions because even when they express their dissatisfaction, they classify the access to the service as excellent or good.

An interesting issue, which allows expanding the discussion exposed here, refers to the way expectations are expressed. In the narrative of the older users, when talking about the access to the scheduled consultation, they point out the need for weekly assistance.

Some authors highlight that in the public sector, the evaluation done by the users involves a more complex interaction of the elements, including those that influence perceptions about public services. Thefeeling of gratitude would be common in peripheral countries, which hinders a more critical view of the assistance. Patients would avoid criticizing the services due to this bias, both for fear of losing access and because of their dependency on health professionals.

On the one hand, the culture, the principles, and the specific values of the public sector, and on the other hand, the expectations of each user, formed by their previous experiences and by information transmitted by the media are aspects that must be taken into account in these evaluations. Perceptions are part of the political and civic culture, comprising values, beliefs, representations, and attitudes regarding citizen's rights andobligations, which are constructed from present and past experiences. In very unequal contexts, for certain segments of the population, the usual difficulty in accessing assistance leads to low expectations. The simple fact of being assisted can generate satisfaction, because these people do not expect much of public institutions. ${ }^{11}$

Among the obstacles faced by users inside the Family Health Units are the non-distribution of medication and the non-performance of procedures (such as clinical exams, dressings, aerosol, vaccination, simple suture excision, among others) in the unit itself.
The majority of users classified as regular, poor, extremely poor, or could not tell whether the distribution of medication and procedures were performed in the health unit, reaching $71.09 \%$ of dissatisfaction. When this data is confronted with the interviews with the users of the FHU Blue and Green, this percentage is corroborated, confirming the user's dissatisfaction with the lack of access to these procedures. The narratives manifested the difficulty in the continuing care, which forces the users to seek another service, in this case, a service of reference in the secondary care level to perform something that is of the primary care scope in the first level of care. They also report difficulty in reaching this other service because of the distance and the problems faced with lines in this secondary health service.

Something unusual was reminded by one of the users, the collection of the blood sample in the household in specific situations, pointing out that the health service can provide special care in situations of extreme fragility of the user, although the performance of clinical exams in the FHU is a very strong expectation of the interviewed users.

One of the exclusive aspects for the evaluation of primary care is the integrality that involves several kinds of information. The development of activities is one of them which is related to the needs of the population. These needs include primary and secondary preventive activities, such as immunizations, health education, and procedures of referred exams, as well as activities directed to the detection and management of health problems in the assisted community. ${ }^{9}$

The lack of distribution of medication, collection of materials and procedures may indicate that medical activities are being privileged in these health units, compromising the integrality and continuing care, even when there is the possibility of continuity of these actions, considered basic in the primary care, to be done in other health services. The lack of these activities is pointed out by users as generators of dissatisfaction regarding the health service.

Another very important item, which fits in the organizational accessibility and which interferes in the assistance to the user inside the unit refers to the time spent in the waiting room for both the schedule and eventual appointments.

Users complain about the delay in the medical assistance in the waiting room, especially when it is an eventual appointment, because the user arrives at the unit with a specific complaint and desires to be assisted immediately. However, others understand that when it 
is an eventual appointment the user has to wait, unless it is a situation/problem/complaint that demands immediate intervention by the part of the team.

Many suggested that assistance must be prioritized, according to the severity of the problem; the more severe and acute the problem, the faster the patient should be assisted. Others had already perceived this is already done.

The welcoming in theFHU is performed by nursing auxiliaries, whostay at the reception and by the nurse when needed. However, there are many complaints regarding the wait time when the patient is feeling sick. Sometimes, the user does not understand the severity of his/her problem or whether (s)he can wait the time demanded by the unit. Additionally, other values are involved such as immediate culture and others.

However, in general, we can observe that the waiting time variable is very subjective and relative to each individual, depending a lot on the user's expectations and previous experiences. Regarding the waiting limit, some say the ideal would be to be immediately assisted; others would tolerate a delay of 30 minutes, others even two hours, other users compare the waiting time in the private service, and others would wait the necessary time with no problem.

In the public sector, the user can either put him/ herself in the consumer role, evaluating the services from his/her individual gains, or in the citizen role, evaluating the services taking into account the society as a whole. As a consumer, (s)he can desire a shorter waiting time for the appointments and faster assistance. However, as a citizen, (s)he may want all people to be assisted, which implies longer waiting periods. ${ }^{11}$

\section{Humanization of the Family Health assis- tance-details that make the difference in the production of health care}

The interaction between the team and the user of the FHU provides great satisfaction for the users because it represents a differentiated relationship, marked by attentive and affective interpersonal relationships. The users report being treated with respect, courtesy, being welcomed in the unit, perceiving interest and concern for their complaints, an attentive and dignified assistance, a qualified listening, and responsibility regarding their problems. They emphasize the warming assistance, easy access to professionals, even the physicians, and the existence of a certain familiarity, bond, and the presence of continuing care.

Small gestures, small details: the physician shakes hands when leaving. (002FHU GREEN). Gestures that are valued by the user as essential in the health care delivered to the solution of a health problem, but oftentimes not valued and not taught to the health professional, "because they seem too obvious". 14:54

One of the important questions in establishing bonds in health care work is the "flexibility learning, qualified listening, attentive to what is not said, identification of other needs that are marked by the subjectivity present in the relationships [...] the complexity of the meetings that favor quality bonds, revealing the learning that good meetings depend on the care with small but important details". ${ }^{14: 59-64}$ Details present in everyday routines, but permanently available to act in health, being necessary however, that they are perceived and valued.

The medical, nursing, and reception assistance, as well as the work of the Communitarian Agents were highlighted as marked by the presence of a more humane, personal care, a welcoming posture; users recognize the professional by name, bond, familiarity for living in the same neighborhood, for knowing his/her family, house, which seems to form the continuing care as an essential element in primary health care work.

In the different spaces of care, there is communication between professionals and users and the possibility of establishing intercessor spaces, where exchanges between professional and the user and intervention about the user's problem are present in unique moments, single in the search of production of care that meet the needs and expectations of the users. In that sense, the educational groups developed in theFHU, although little mentioned by users, can be moments of exchange and intervention.

The user hopes to be welcomed in the relationship with the health worker, find a solution for his/her problem, and to observe actions that are effective and satisfactory. In this sense, the exchange of information, experiences, and knowledge, in which everybody see 0 themselves as one who teaches and learns; seem to be fundamental in the production of care in health. ${ }^{14}$

Care that is also expressed in the physical space where the care is processed, in the ambience ${ }^{\ddagger}$,

\$ This concept has been used by the Ministry of Health, in the National Policy of Humanization, expanding its meaning and the meaning of physical space and infra-structure. ${ }^{15}$ 
in which the health refers to the treatment given to the physical space understood as the social, professional and interpersonal relations space, which must provide welcoming, resolute and human care.

Although there is a high percentage of excellent and good scores regarding the physical appearance, the users' dissatisfaction regarding the ambience is evidenced in the speeches, while their complaints are related mainly to the waiting room, characterized as a small, tiny room, without proper illumination or adequate heat, without privacy, comfort, with old furniture, sometimes mentioned as a dirty place, not resembling a health service, poor painting, and humid walls. In summary, it is an ugly place for delivering health services. Another obstacle was the lack of adequate access for physically-deficient people inside the health units, not meeting all the individual's needs, not considering the integrality of care.

Besides being pointed out as a modest place, what calls the attention within the speeches is with regard to the dirt in the health unit. A "non-cared-for" environment producing "care for people".

When analyzing the ambience, the majority of the users relate it with the interaction established with the health team or with the geographical accessibility and classify it as good, despite expressing several complaints regarding the infra-structure. Therefore, it is an important factor to be revised by the team and managers.

\section{The search for quality of care}

Quality of care means how well the existent or potential health needs are being met in an optimized wayby the health services, given the current knowledge and concerns regarding health. ${ }^{9}$

The term quality is also used in the ample sense to reflect not only quality of care as defined above, but also to define satisfaction regarding the services, the care costs, the qualification of health services, the security and nice appearance of the health units in which the services aredelivered, and the adequate equipment which contribute to the delivery of services process. The satisfaction with the services is directly related to the quality because it can influence the search for certain types of services that in turn influence the patients' health state. ${ }^{9}$

Trustworthiness is recurrent in the users' speeches. Having trust, feeling confident (045FHU BLUE), translate the perspective of letting the other take care of a precious good-health, a "symbolic good" to the user, ${ }^{16}$ something considered as inestimable and unique.
The majority of users $(87.7 \%)$ show satisfaction regarding the competency and technical quality of the health team, affirming to have confidence in the team, having always received the adequate diagnosis, treatment, and guidance. An interesting affirmation of one of the users was the relationship he established between the competencies of the team with the daily frequency of the professionals in the unit: they are never absent, every day they're on time (076FHU BLUE).

Some users, however, raise some doubts regarding the technical competency of the team, expressing insecurity because it is a health service-school, for being assisted by students or for having had some experience with error in treatment or diagnosis.

The users oftentimes resent the assistance being delivered by interns and this issue is reinforced by strong statements [...] need some guinea pig to learn... (010FHU GREEN) or [...] maybe a little doctor, a less experienced intern (028FHU GREEN). In addition to the desire for a closer relationship of trustworthiness which is built over time, they also expect the professional (or intern) who assists them to have clinical experience, although they recognize the need for training in the health services. The figure of the "professor" who helps to acquire such competence is also present and is recognized as important by the users.

The time of assistance allocated to the patient and the waiting time for the intervention are components of evaluation measurements of welcoming, besides the degree of information of the user regarding his/her problem and whether what was done solved the problem in relation to the user's expectations. ${ }^{14}$

In the analysis of the time spent inside the office during a medical or nursing appointment, users $(90.1 \%)$ showed satisfaction, affirming that this long time spent in the office is a factor of quality in the assistance. They report high attention, qualified listening, valorization of their complaints, judicious collection of data for the anamnesis, examine everything, head to toes (049FHU BLUE), they feel cared for, and compare with other fast assistance they had received. The complaints expressed were directed to the fact it is a health service-school, while some users mentioned that the students or interns take more time in the assistance, because during the appointments they have to leave the office to discuss the case with some professor or hired physician and it causes delay, especially for those who have time to go back to work. 
The users included in their speeches the issue of quality and quantity of equipments, as an aspect of quality in the assistance of FHU. The majority $(83.6 \%)$ reported that the existing equipments are in good working conditions and it seems there is adequate quantity, also mentioning the most used equipments, such as: infant and adult scales, sphygmomanometer, stethoscope, glycosometer, ostoscope, speculum, and ultrasonic detector. The dissatisfied users mentioned quantity as an obstacle in the assistance, reporting few types of equipment were functioning and many interns, which increase delay in the assistance, with some affirming there is the need for other equipment in the FHU, such as an X-Ray.

Another aspect that emerged from the set of narratives, which demonstrate quality in the assistance, was the supply of some services and assistance by the FHU that differentiate it from other health units in the primary care level. The most cited ones were the collection of exams in the household, the communication by telephone to warn patients in case the exam is altered, the visit in the residence to follow up the family health situation, educational groups in the unit, the team responsibility for the patient (the team seeks to learn the reason patients did not return to the units).

Users affirm their disposition in indicating the FHU to some relative or friend, justifying the relationship they have with the team, the good assistance, the respectful, affective, attentive and polite way they are treated and because of the bond established with the team. They highlight the proximity of the service to their house, besides the fact that the health service is where all the follow up is performed, while some report the FHU is better than a private service.

The "resolutive action" means going beyond the conduct, in a way the worker knows how to use all the technology available to get to the adequate diagnosis and treatment for each case, changing the user's condition in a satisfactory way. ${ }^{14}$ The concept of problem-solving capacity implies that when a person seeks assistance, or when there is a problem of collective impact in health, the health service, according to its competencies, can meet the existing demand.

\section{FINAL CONSIDERATIONS}

The evaluation of the health services through the perceptions of users has been considered an important instrument in the managerial work process, as it allows managers of these services to rethink the assistance delivered and consequently, satisfy the expectations of these users. ${ }^{16}$

The possibility of developing a quantitative-qualitative study allows for a differentiated analysis, because despite the satisfaction expressed by the users evidenced by the quantitative data, contradictions were observed in the speeches of these same users. Thus, this mixed analysis permitted the identification and deepening of their dissatisfactions, revealing aspects of the services that need to be improved and thus, contributing to the decision making process.

This study counts upon the analysis of distinct dimensions and acceptability indicators, assuring a more ample comprehension of the services in the view of users for each dimension explored, allowing a more precise action on the factors that must be improved.

The evaluation of satisfaction of the users of public services gives the users opportunities to express themselves, who can provide support to monitor and control the activities of the public health services, favoring their participation in the planning processes and exercising social control. ${ }^{7}$

We recognize that there is a set of commentaries and limitations regarding studies on users' satisfaction that relates to the subjective aspect of the category "satisfaction", which possesses several determinants such as: degree of expectation and individual demands regarding the assistance and individual characteristics of the patient (age, gender, social class, and psychological state). ${ }^{7}$ However, the quality of services depends on an interaction, an exchange relationship between the subjects who experience the same social condition. Thus, it is essential to analyze the satisfaction of the user, the one who is directly favored by the service and is part of the organization and delivery processes of these actions. Therefore, these studies allow for the construction of alternatives jointly to the health services and users, regarding interventions in agreement with problems and identified situations, aiming at improving the routine of the health services, permitting important advancements in the scope of the production of care and management of health services.

\section{REFERENCES}

1 Ministério da Saúde (BR), Secretaria de Políticas de Saúde. Departamento de Atenção Básica. Avaliação da implementação do Programa Saúde da Família em dez grandes centros urbanos: síntese dos principais resultados. Brasília (DF): MS; 2002. 
2 Ministério da Saúde (BR), DATAUnB Pesquisas Sociais Aplicadas, Centro de Pesquisas sobre Opinião Pública da Universidade de Brasília. Pesquisa Nacional de Avaliação da Satisfação dos Usuários do SUS. Brasília (DF): MS/UnB; 2006 [acesso em 2006 Mar 06]. Disponível em: http://portal.saude.gov.br/ portal/arquivos/pdf/resumo_do_projeto_satisfacao_ usuarios_sus.pdf

3 Donabedian A. The seven pillars of quality. Arch. Pathol. Lab. Med. 1990 Nov; 114 (11): 1115-8.

4 Junqueira LAP, Auge APF. Qualidade dos serviços de saúde e satisfação do usuário. Cad. Fundap 1995; 19: 60-78.

5 Tanaka OY, Melo C. Reflexões sobre a avaliação em serviços de saúde e a adoção das abordagens qualitativa e quantitativa. In: Bosi MLM, Mercado FJ, organizadores. Pesquisa qualitativa de serviços de saúde. Petrópolis (RJ): Vozes; 2004. p.121-36.

6 Ministério da Saúde (BR), Secretaria de Assistência à Saúde, Coordenação de Saúde da Comunidade. SIAB: manual do sistema de informação de atenção básica. Brasília (DF): MS; 1998.

7 Esperidião MA, Trad LAB. Avaliação de satisfação de usuários: considerações teórico-conceituais. Cad. Saúde Pública. 2006 Jun; 22 (6): 1267-76.

8 Travassos C, Oliveira EXG, Viacava F. Desigualdades geográficas e sociais no acesso aos serviços de saúde no Brasil: 1998 e 2003. Ciência Saúde Coletiva. 2006 Out-Dez; 11 (4): 975-86.

9 Starfield B. Atenção primária: equilíbrio entre necessidades de saúde, serviços e tecnologia. Brasília (DF): UNESCO; 2002.

10 Fekete MC. Estudo da acessibilidade na avaliação dos serviços de saúde. Unidade 3. In: Santana JP, organizador. Desenvolvimento gerencial de unidades básicas do Sistema Único de Saúde (SUS). Brasília (DF): OPAS; 1997. p.114-20.

11 Vaitsman J, Andrade GRB. Satisfação e responsividade: formas de medir a qualidade e a humanização da assistência à saúde. Ciência Saúde Coletiva. $2005 \mathrm{Jul}-\mathrm{Set}$; 10 (3): 599-613.

12 Pinheiro RJ, Viacava F, Travassos C, Brito AS. Gênero, morbidade, acesso e utilização de serviços de saúde no Brasil. Ciência Saúde Coletiva. 2002 Nov; 7 (4): 687-707.

13 Franceschini TRC. Observação da relação mãe-bebêfamília como uma ferramenta para o aprendizado da integralidade [dissertação]. Ribeirão Preto (SP): USP/ EERP; 2005.

14 MerhyEE. Em buscada qualidade dos serviços de saúde: os serviços de porta aberta e o modelo tecno-assistencial em defesa da vida (ou como aproveitar os ruídos do cotidiano dos serviços de saúde e colegiadamente reorganizar o processo de trabalho na busca da qualidade das ações de saúde).In: CecílioLCOC.Inventandoa mudança nasaúde. São Paulo (SP): Hucitec; 1994. p.117-60.

15 Ministério da Saúde (BR), Secretaria-Executiva. Núcleo TécnicodaPolíticaNacionaldeHumanização.Ambiência. Brasília (DF): MS; 2006.

16 Merhy EE. Em busca do tempo perdido: a micropolítica do trabalho vivo em saúde. In: Merhy EE, Onocko R, organizadores. Agir em saúde: um desafio para o público. São Paulo (SP)/Buenos Aires (AR): Hucitec/Lugar Editorial; 1997. p.71-112.

17 Tronchin DMR, Melleiro MM, Tsunechiro MA, Gualda DMR. O olhar dos usuários de um hospital de ensino: uma análise da qualidade assistencial às gestantes e aos recém-nascidos. Texto Contexto Enferm. 2006 Jul-Set; 15 (3): 401-8. 